\title{
EDUCATION BASED ON COMPETENCES: PROJECT - BASED LEARNING AND VIRTUAL PlATFORM
}

\author{
FENOLLERA, M. \& GOICOECHEA, I.
}

Abstract: This study is focused on applying a competence-based education model to the Projects subject at the School of Industrial Engineering, University of Vigo. The aim has been to try to adapt to Bologna Process before it affects the subject in order to gain experience, to apply learned lesson and to change the working method and teacher's assessment. The two pillars of this experience have been: Project-Based Learning $(P B L)$ and Virtual Learning. These two educational methodologies have been implemented in two consecutive stages, one year for each methodology.

The paper will deal with this model design presentation; the different experienced training activities; the solutions that allowed for capacities, abilities and attitudes; organization criteria and some thoughts derived from its development.

Key words: European higher education area, competences, project-based learning, virtual platform.
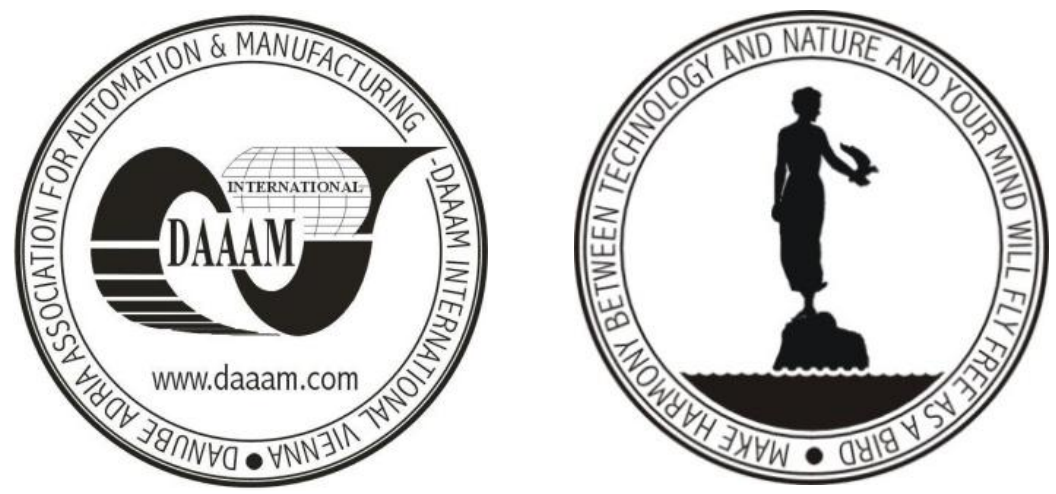

Authors data: Univ. Prof. Eng. Fenollera, M[aria]; Dr. Eng. Goicoechea, I[tziar]; University of Vigo, E.T.S.Industrial Engineers. Campus Lagoas Marcosende s/n Vigo.Spain,mfenollera@uvigo.es, igoicoechea@uvigo.es

This Publication has to be referred as: Fenollera, M[aria] \& Goicoechea, I[tziar] (2011). Education Based on Competences: Project - Based Learning and Virtual Platform, Chapter 14 in DAAAM International Scientific Book 2011, pp. 165-180, B. Katalinic (Ed.), Published by DAAAM International, ISBN 978-3-901509-84-1, ISSN 1726-9687,Vienna, Austria

DOI: $10.2507 /$ daaam.scibook.2011.14 


\section{Introduction}

Up until 2001, the Degree in Industrial Engineering of the University of Vigo had the former 6-year long Study Program (dated 1982), where the Projects subject had 6 theory credits. When the current Study Program came into force in 2001 at Industrial Engineering Schools, the degree went from 6 to 5 years, and the Projects subject has now 3 theory credits and 3 practice credits.

This Study Program is still in force until the $5^{\text {th }}$ course, where the Projects subject is taught, finishes, and the Bologna's grades are being gradually introduced year after year, the 2010/2011 year being its first time at the University of Vigo. Each grade will last 4 years and the subject object of study will be taught in the $3^{\text {rd }}$ year in some grades and in the $4^{\text {th }}$ in others.

Projects is presently a compulsory subject, common to all specialities, chosen by many students (about 250 from different specialties), with 4 teachers to evaluate them. As for Bologna grades, the situation will change significantly, since the students will be already in different grades by specialty from the $1^{\text {st }}$ year, so groups will be less heterogeneous; furthermore, the number of students will go down considerably: there will be about 50 .

This experience arises from the need to adapt the Spanish University System to the new teaching model of the European Higher Education Area (2010), derived from the Bologna Declaration (1999) and is aimed at obtaining specific and crosscurricular competence, launched through project-based teaching and the virtual platform Claroline. It has been implemented in the following stages:

- Conducting a project applying gained knowledge and abilities. Broadly speaking, teaching is provided about theoretical matters applicable to any aspect of the project and that knowledge is developed in the form of a practical project supervised by the tutor teacher assigned to each group.

- The use of the FaiTIC distance-teaching platform based on the Claroline platform with the aim of virtually completing classroom teaching.

\section{Theoretical Research Approaches}

\subsection{European Higher Education Area (EHEA)}

Since the Bologna Process was first applied to the University in Spain, the University system has undergone a significant change. The different innovations and reforms being carried out to integrate it into the European Higher Education Area (EHEA) are focused on Competency Based Education (Diaz, 2006). Shift has been made from teacher-centered lessons only conducted by the teacher, to studentcentered teaching, with a closer individualized tracking that will lead students to pass subjects. Thus, the new active teaching methodologies propose a change in focus, the main role being given to the student, always followed and motivated by the corresponding teacher. In this new scenario the student's direct involvement is sought in the preparation of the teaching contents that will have a bearing on his education (Benito \& Cruz, 2005).

This change of model entails an important effort for teachers to get adapted from the traditional knowledge-based teaching method: the new approach is about 
being able to create knowledge instead of transmitting it. The arousal of these new keys for teaching must be an encouragement for teaching, and the necessary adaptation of teachers to these new active methodologies will enrich students' education and learning, final aim of the teaching work (Knight, 2005). Even more, universities play a new social role as lifelong education and learning centers, implemented in multiple specialized, master and postgraduate courses. Such role, in accordance to the increasingly closer relationship between universities and companies (both regarding investigation and education), means more competences being achieved by teachers and students, and this forces an academic synergy between them so that the best results are attained.

\subsection{Virtual learning}

In this context, e-learning or distance learning is understood as stated by Buzón (2005), not simply as distance learning, but as a distance learning teaching method, supported by Information and Communication Technologies (ICTs), combining different pedagogic resources. The attendance and non attendance, as well as the ideas about the use of learning times, individual work capacity and group learner capacity, information structuring and teacher's new working methods are qualities that distance learning brings about to teaching-learning processes.

These new systems offer users a personalized education, as well as the possibility of establishing a continuous tracking on students, of their progress, optimizing learning processes and removing some problems related to classroom instruction, such as lack of time and spaces. Therefore, what we have is an educational environment that aims at fostering cooperative learning, among students and teachers, among teachers themselves and among a class and wider, academic and non-academic communities.

Currently, the new ICTs have given a new meaning to education. In the higher education sector, it is causing a far-reaching organizational change (Pino, 2010). In fact, e-Learning plays a key role in the innovation process of universities (Schneckenberg, 2004), since it allows the design and inclusion of innovative educational interventions during the teaching-learning process both initially and throughout an individual's professional career (Gallego, 2003), although many times it is carried out poorly planned (Álvarez, 2003). Hence the importance of optimizing e-Learning systems (López \& López, 2002), rationalizing and justifying this learning system to create interaction environments between students and course materials (Tascón, 2004).

At the University of Vigo we have the FaiTIC distance-teaching platform, aimed at virtually complement classroom teaching. This platform was initially based on the Claroline platform, developed by the Catholic University of Louvain that recently integrated with the Moodle platform, developed by Martin Dougiamas. Both are open source and e-Working platforms.

We have decided to use Claroline because it gathers specific and particular characteristics of Content Management Systems, best known as CMS, such as being totally dynamic, highly configurable, versatile and simple when it comes to modifying its contents. It allows for almost instant administration of e-Learning courses and control the following tasks: to publish documents in any format (.doc, .odt, ppt, pdf); administrate and model discussion forums, both public and private; to 
administrate listings of reference links; create study groups; make practice exercises; structure and administrate an agenda of events, tasks and deadlines; control course users or students; administrate each course instructors and teachers; handle students' deliveries (documents, tasks, works, etc.); manage and store the Chats that teacher and students can establish; complete follow-up by means of statistics of the students in the classes; and assess through multiple choice system.

This platform allows us to set up different and varied activities and learning methods (individual and group) that will imply overcoming fear regarding the use and command of ICTs and to put learnt concepts into practice. Apart from its tools (synchronous and asynchronous), the platform allows us to track each student individually, as well as to set up group/individual virtual tutorials, serving each student's needs and respecting their learning pace.

The use of a virtual environment for teaching the Projects subject reinforces traditional teaching, makes use of the possibilities available to spread teaching material, to temporary link theoretic concepts and its practical application, to foster students' interest and to monitor their learning.

In order to achieve these objectives, the teaching Claroline platform is established as the main virtual space containing different components linked to teaching the subject. It stands out for being user-friendly, as opposed to other kinds of platforms (Plantak et al., 2010; Casar, 2006 \& De Henao, 2007); it has been adapted to the teachers' needs by the University of Vigo and its maintenance is assured by a specific university service (FaiTIC).

\subsection{Project Based Learning (PBL)}

Active methodologies, PBL in particular, present a perfect adaptation in engineering teaching, since future engineers will have to adopt similar methodologies in the work world. PBL is a learning method in which students plan, implement and evaluate projects that have real-world applications beyond the classroom (Blank, 1997; Dickinson, 1998 \& Harwell, 1997). This model has its roots in the constructivism views that evolved from the work of psychologists and educators such as Lev Vygotsky (1978), Jerome Bruner (1990), Jean Piaget (2001) and John Dewey (1998).

The PBL was advantageous for higher education institutions as regards students' learning and competence acquisition. As for learning, students are motivated when engaged in project and group-based pedagogy practices. Specifically, this means shorter study time for students and lower student dropout rates. As for competences, students obtain those corresponding to the knowledge-based society and that are for life.

Currently, it is considered that PBL might be one of the suitable methods for the new learning-based higher education models and this is supported by the studies of Woods et al. (2000), Oliver (2003) and Thomas (2000), among others.

This method's initial experiences began in biomedical sciences (Barrows, 1980); subsequently other disciplines, including computer science have also used PBL: Larsen et al. (2003), Striege et al. (2002) and Uden et al. (2004). According to Barrows, PBL can be explained as "the learning that results from the process of working toward the understanding or resolution of a problem". He fully describes a set of generic PBL essentials, reduced to the bullet points below: 
- Students must have the responsibility for their own learning.

- The problem simulations used in problem-based learning must be ill-structured and allow for free inquiry.

- Learning should be integrated from a wide range of disciplines or subjects.

- What students learn during their self-directed learning must be applied back to the problem with reanalysis and resolution.

- A closing analysis of what has been learned from work with the problem and a discussion of what concepts and principles have been learned are essential.

- Self and peer assessment should be carried out at the completion of each problem and at the end of every curricular unit.

- Student examinations must measure student progress towards the goals of problem-based learning.

- The activities carried out in problem-based learning must be those valued in the real world.

- Collaboration is essential. In the world after university most students will find themselves in jobs where they will need to share information and work productively with others.

- Problem-based learning must be the pedagogical base in the curriculum and not part of a didactic curriculum.

In the light of these principles, we observe that in PBL students are to assume more freedom of action and responsibility. Also, the figure of the teacher assumes a different role: directing the student in the learning process. It has to be a tutor playing an activator rather than facilitator role. The PBL success or failure depends greatly on the teacher-tutor's education and training.

We believe that the PBL should allow for the development of the professional qualities sought in today's world: continuous learning, autonomy, group work, spirit of criticism, communication and planning skills.

\section{Experience description}

At the School of Industrial Engineering, University of Vigo, the teachers from the Engineering Projects Area, which is part of the Design in Engineering Department, have been involved in pilot courses for two years aimed at gradually change the traditional education system to the new framework in the final year Projects subject, common to the Industrial Engineering degrees, that will come into force in two years for this subject, (academic year 2012/2013). Currently, and as part of the new curriculum design process based on the learning-centered and competence-based teaching method, several doubts about how generic or crosscurricular competences are to be distributed and assessed are arising.

This paper will develop the work, the experiences that we had over the past two years and the results obtained in this subject, from the viewpoint of the students' development of general or cross-curricular competences, including activities and assessment procedures used. 
With this aim in mind, we have tried, on the one hand, to use ICTs as tools to achieve the objectives set, and on the other hand, aligned with the main objective, to implement the project-based education model.

\subsection{Framework}

The study presented here has a 4-year time frame and is still developing. It is currently in its third year, even though it is the first two years' experience which is going to be analyzed in this article, where a competence approach has been developed. The final aim set for this experience, after the 4-year study, is the achievement of the competences included in the Verifica Datasheet (Table 1).

\begin{tabular}{|l|}
\hline SPECIFIC COMPETENCES \\
\hline Knowledge and capacities to organize and to manage projects \\
Becoming familiar with a Technical Office organization and working \\
\hline CROSS-CURRICULAR COMPETENCES \\
\hline Analysis and summary \\
Problem solving \\
Oral and written communication knowledge in mother tongue \\
Information management \\
IT applied to curriculum \\
Capacity to organize and plan \\
Decision making \\
Knowledge application \\
Autonomous learning and work \\
Planning changes that improve global systems \\
Adaptation to new situations \\
Creativity \\
Objectification, identification and organization \\
Critical thinking \\
Team work \\
Ability to communicate with experts in the field \\
Leadership \\
\hline
\end{tabular}

Tab. 1. Competences to be accomplished by the student

The name of the subject in the grade will be Technical Office and Projects and will become a compulsory, common subject of the Industrial specialty of the $4^{\text {th }}$ year, and will have 6 credits ECTS distributed as follows: 3 credits for lectures, 2.5 to lab classes and 0.5 for tutorials. Compulsory classroom activities will represent $35 \%$ of student time, whereas distance-learning will do $65 \%$. The above-mentioned are the essentials of this experience.

\subsection{Project-Based Learning methodology}

The pilot experience of the Projects subject started in the academic year 2008/2009; it was taught to all specialties in the second term of Industrial Engineering. All specialties were decided to start at the same time because the four teachers divided the subject by topics and the topic was taught to all specialties. In 
the current Study Program, this is a core, 6-credit subject ( 3 for theory and 3 for practice).

The 230 students enrolled in the Industrial Engineering School this year were divided into four groups for teaching theory in the classroom (one by specialty), and 12 practice groups carried out in the computer lab, three by specialty, the number of students of each being very different from one specialty to another. In the labs each students has a computer, what has helped students a lot to carry out the project.

This first year, the teacher-centered education model was changed to the learning method based on the PBL. This change implies that the student assumes more freedom of action and responsibility and the teacher makes the pace for the student learning process. An initial question was to explain the new teaching methods to the students so that they could understand and accept it despite being used to a traditional learning method. In order to do that, we tried to make the students aware of the objectives pursued and of the benefits to be attained.

PBL working groups of 4-5 people were decided to be established, the group setup being free; the intention was to facilitate class attendance to the different groups, regardless of that corresponding to each student, since most of the students in these degrees are enrolled in subjects from other years and it is therefore very common that lectures overlap.

We bore in mind that the proposed project fulfilled the characteristics of an appropriate PBL project: relevant and interesting for students, with clear objectives and stages and complex in the sense of having different solutions and being interdisciplinary. Many situations of professional real-world can meet these characteristics. We considered making a planning and execution of an industrial building during the whole four-month term. The requirements were selected by the group: they had to focus on a Galician town, get urban planning regulations, choose the activity of the building, its classification... They also had to select a plot available for building, design it, measurements, structural elements, budgets...Although they had to be validated by the teacher. Once defined, they were to be kept throughout the project.

A relevant fact is that the basics of project management and planning are developed in the first topic, both practical and theoretically, and it is that first topic where the work plan was established with several targets to be attained; for each target some documents reflecting carried out actions and obtained results were to be handed out. Groups were asked to use a common format in all documents containing at least: author, date, project, matter, and version.

The Work Plan included:

- Delivery of documents regarding the project chosen and the responsibilities of each of the group's member on the specified dates. Some were individual and some group deliveries both clearly defined and planned. Preliminary design and prototype were defined by these partial deliveries. (Figure 1)

- Final document delivery and public presentation of project by group including requirement specification, project planning, as well as tools and technologies chosen for the development with its justification.

The Work Plan was scheduled as shown in Figure 1, and Figure 2 shows, like example, a collage of a project's public presentation developed by a group of student. 
Fenollera, M. \& Goicoechea, I.: Education Based on Competences: Project-Bas...

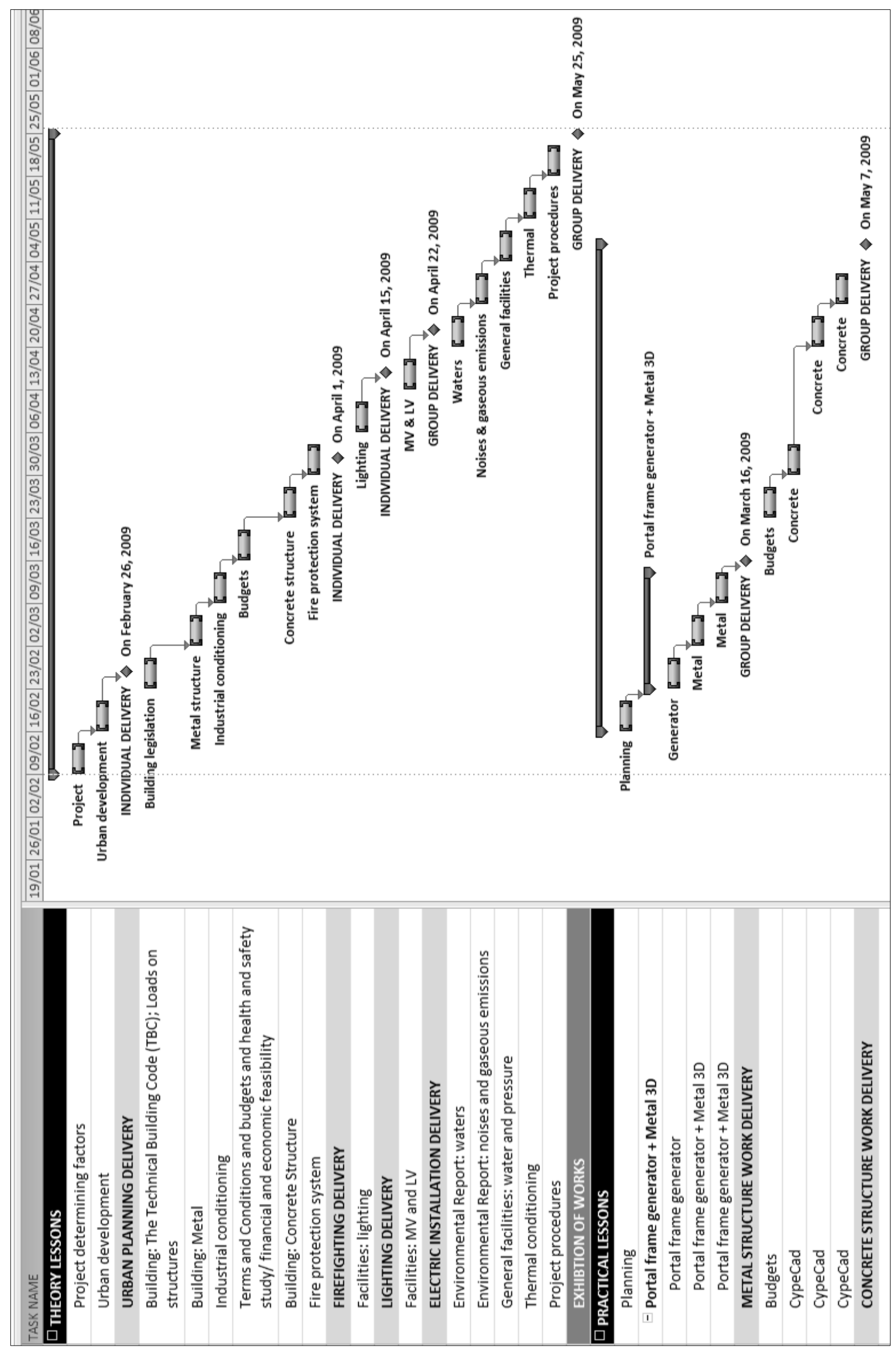

Fig. 1. Project's Work Plan 


\begin{tabular}{lll}
\hline \hline DAAAM INTERNATIONAL SCIENTIFIC BOOK 2011 & pp. 165-180 & CHAPTER 14 \\
\hline \hline
\end{tabular}

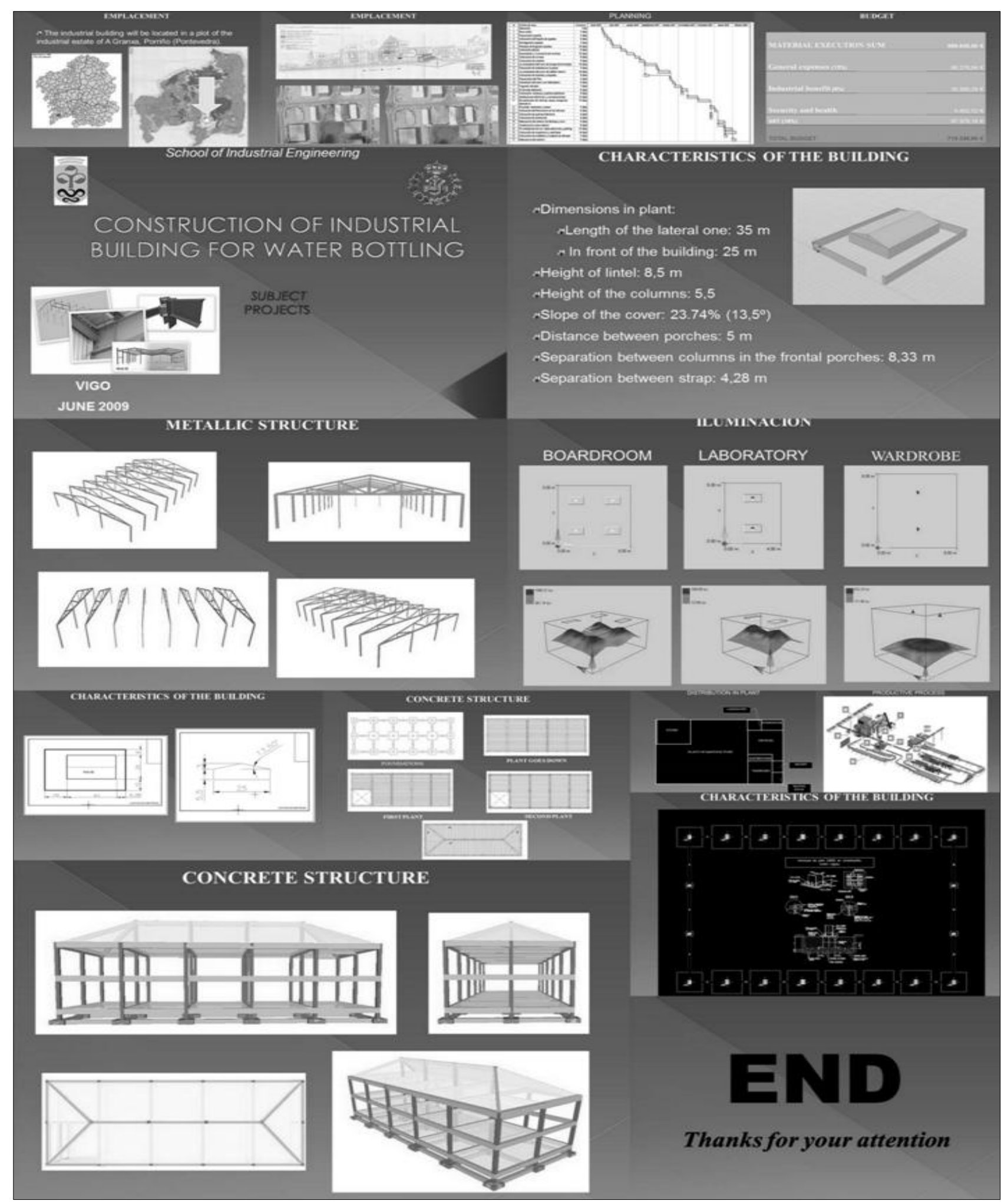

Fig. 2. Collage of a Project's public presentation developed by students

The material resources available to conduct the project in practical classes were chosen by the teachers, proposing, as an important methodological aspect, to foster students' participation in the development of the lectures, and therefore we opted for commercial software, easily accessible by students so that they could work with them in class and during the hours assigned to them outside class schedule.

The functions represented by the teacher in formal education and corresponding tutorials have been as follow: 
- Propose the problem to be solved.

- Initially provide basic knowledge about topics.

- Play the role of the client commissioning the project.

- Critically assess the documents supplied in public presentations.

- Meet with students to check the correct development of the different project stages and task distribution within the groups; also, make learning easy for students by asking questions or alternatives, encouraging them to find their own possible solutions.

\subsection{Virtual learning methodology}

Since 2005, the platform has been used in this subject considering its flexibility and ease of action but only as a repository or for students to upload their works.

During the academic year 2009/2010, a further step was taken towards the achievement of general or cross-curricular competences by students, including the use of TICs as tools to get the objectives set.

Starting from the same study group, but having 219 students enrolled this year, group and student allocation has been practically the same as the previous year. The number of teachers has also been the same, four.

The subject is split into fifteen theoretical topics of 2 hours each and four practice topics, two 3-hour and another two 9-hour topics. The theory lectures last 2 hours and lab practices last 3 hours.

Materials for study and complementary reading can be found on the platform in an organized way with the following formats: presentations, text files, rules, standards, latest news, drawings, images, videos, websites, etc. Figure 3 shows the subject's presentation.

Also included is a series of activities related to competence assessment that will be explained in detail in the next section, as well as a forum to clear up any doubts. They can also be asked by e-mail or in person to the subject teachers.

The presentation of objectives, methodologies and procedures for following up on the subject was done the first day of the course in the classroom.

The calendar of teaching and assessment activities is included in the tutorial published in the virtual learning environment, as well as the rest of teaching and assessment material that was followed from that first on-site class through the Claroline online learning management system.

Some assessment procedures have been established to check that competences are attained:

- Multiple-choice test in practical lectures, in labs, regarding key topics. Enable online assessment for a limited period of time and for all students at the same time. The aim is both to confirm the acquisition of some specific knowledge and to attain some information searching and selection skills.

- Written report about a topic for study proposed by the teacher made through cooperative group work. It basically involved searching for information and creating a document in electronic format in which all group members participated through a suitable task distribution and keeping a uniform format and structure. 
The aim was to train students in group work competencies by using the Internet. The estimated time was 35 hours and a proportion was allocated in the final mark.

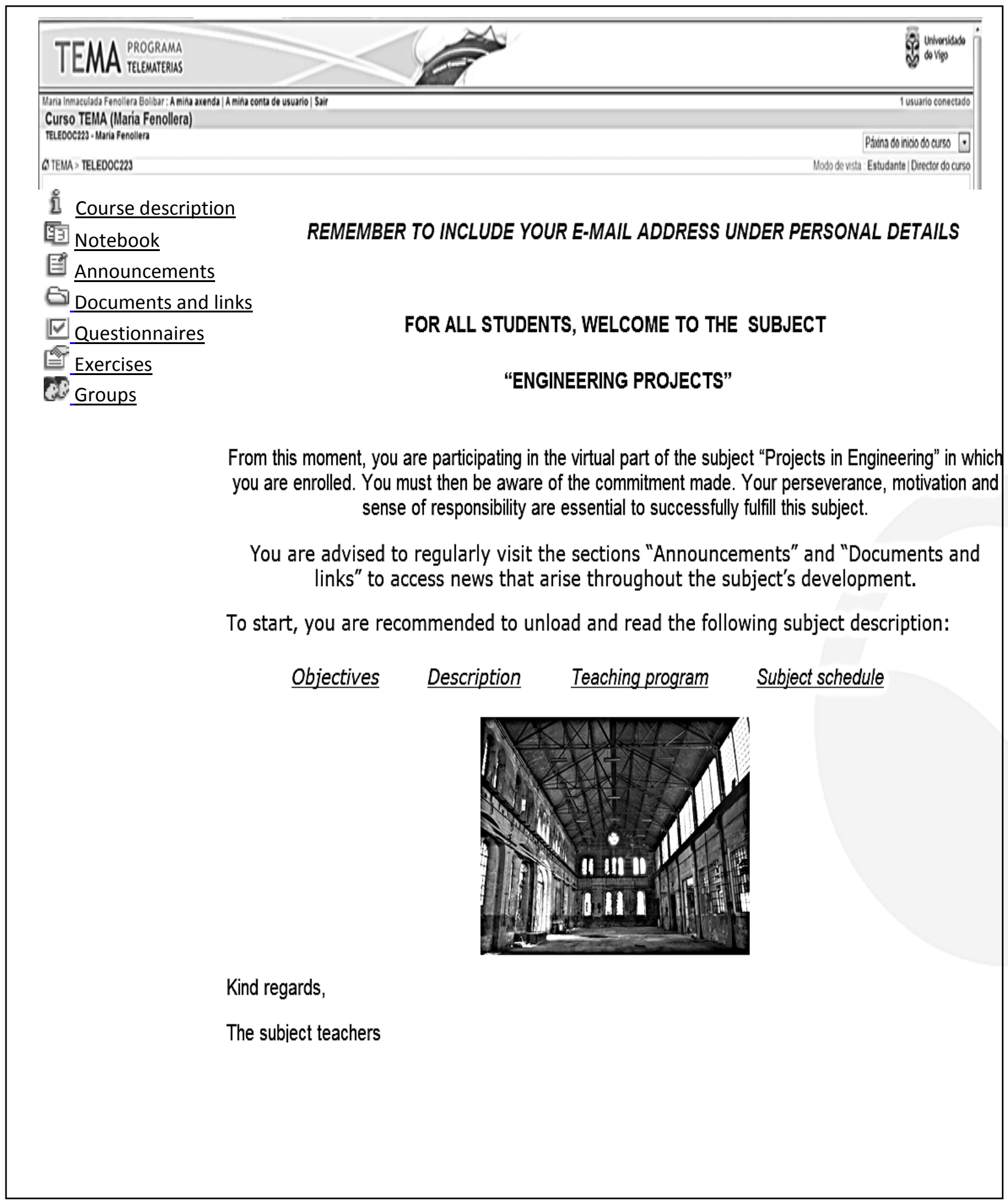

Fig. 3. Project subject presentation in the virtual environment. Year 2009/2010

\section{Results and discussion}

Very good academic results have been obtained in this subject at the end of these two years, as it can be observed in Figure 4, with a follow-up and success rate close to $95 \%$. 


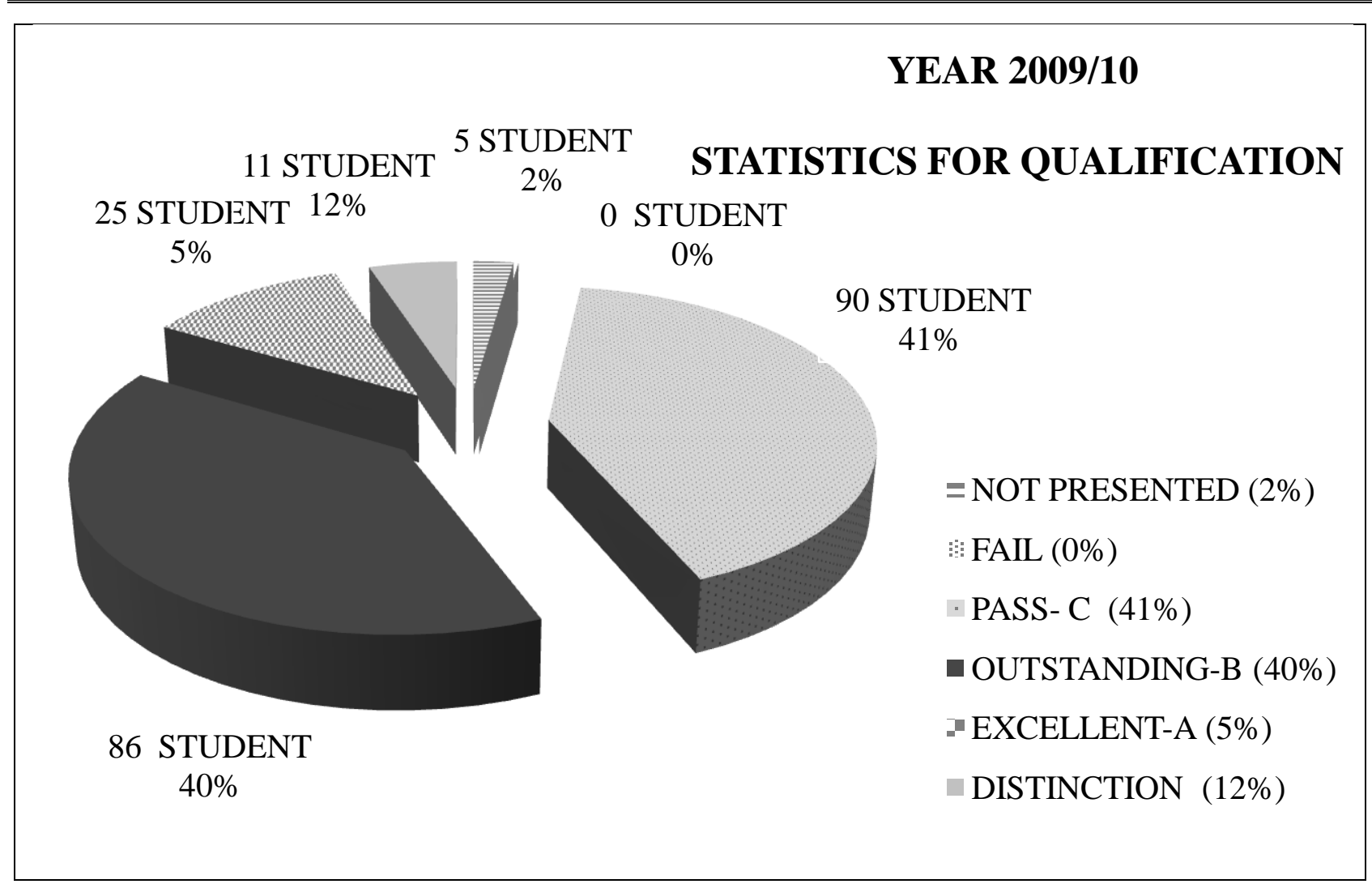

Fig. 4. Year 2009/2010 academic results after a 2-year experience

The percentage of students that did not take the final test is in keeping with those students not following the continuous assessment procedure proposed in this experience. So, it can be deducted that the change in the teaching method has been positive, although it is true that the students complained (during their personal interviews in tutorials) about this new way of working requiring a bigger effort. This can be due to the students not being used to this and being more familiar with more structured works, with less freedom of action and responsibility.

There was not a specific tutor by group, the four teachers tutored all the groups; this partly arose from teaching by topics instead of by groups. This implied a good coordination among them, which was hard in the beginning, since the students tended to repeatedly ask all the teachers about the same topics, searching for the one that made their work easier. Teachers' weekly meetings were set to sort these initial difficulties out.

The change in the tutoring method (the teacher contributes orientations, references, bibliography, aiming for the student to obtain answers himself) was regarded by some students as teachers' disregard, which could be seen in them asking for more help. We consider that such feeling will diminish with more practice from the teachers' side and making more use of these active methodologies.

Another aspect that came to light was that some students felt distressed at not being able to do the project (mainly during the first year) because they saw the project as their first work of some magnitude, and this caused insecurity. However, it is true that from that year on the number of students that requested to do their finalyear dissertation tutored by these teachers increased, from what we can conclude that students viewed the experience positively. 
In the personal interviews, the students mentioned the problem of not having enough time. The beginning of the project carrying out was especially delayed in many groups, either because the project size was not correctly estimated and therefore there was a wrong planning, or because the planning done was not properly observed, or because the documents included in the virtual environment could seem excessive when compared to those of the traditional method.

As positive, they mentioned continuous assessment, that is, the possibility of passing the subject with only one work, thus freeing themselves from the much feared final test. It could also be checked that the knowledge learned from previous subjects was not sufficiently fixed, or there was immaturity to use it, due in part to the current curriculum offering, in some cases, a view of the subjects as watertight compartments.

\section{Final reflections}

The teachers of the Projects subject are aware that drawing definitive conclusions from a first experience in a field can be risky and that most of the difficulties arisen were mainly due to students and teachers being unaccustomed. Anyhow, we would like to make the following reflections:

- For the students, this change is the step previous to the final-year dissertation as regards subject integration. Contribution has been made to stop seeing subjects as isolated; such situation is far from professional reality, where the questions arisen are generally interdisciplinary.

- Learning, group work, time management, oral and written communication are practised. Work is also distributed along the whole four-month term, avoiding usual final efforts.

- For the teachers, even though it has been a huge effort, particularly when it came to do group work for teaching, we consider this a good trial for the adaptation to the goal set for defining and evaluating the necessary competences. The good results obtained encourage us to make a positive assessment.

- The properly scheduled three-hour working sessions, particularly for practical lectures, makes it easier for students to be immersed in the problem longer, and this implies being more aware of the business world, where there is no jumping from one issue to another every hour. Given this approach, they can change tasks (group meetings, individual work, and interviews with teachers) during that time.

- As it has been shown by this study, the use of virtual learning platforms is useful not only as a repository of material and learning elements, but they also enable suitable organization, planning and competence-based assessment.

Despite the difficulties, the final result was very satisfactory and although we are halfway toward the objectives set we hold out for new procedures to get such objectives. Thus, this academic year 2010/2011 several online initiatives are being carried out, such as discussion and doubt forums, work and presentation templates and self-assessment tests. Additionally, an assessment table or rubric is being conducted in order to assess cross-curricular competences sought. The option of including (as an activity) the attendance of professionals, managers and people who 
have important roles in renowned institutions in the field of the subject to conferences (and a subsequent discussion with the students), is being valued.

\section{Conclusion}

The shift of the traditional paradigm (which in the case of engineering degrees in the last few years was in many times based on a master class together with the delivery of practicals) means an effort that not everybody is willing to assume. However, teachers and students' general feeling is positive and they are convinced that the path chosen two years ago is the correct one.

The application of these methodologies and educational tools not only implies more work from the teacher side in class, but also a previous preparation time of specifications for guided sessions, documents regarding how to confront with the challenge of making the project, search for additional bibliography to foster selflearning, set new metrics to assess students, summary of theoretical contents taught, establishment of detailed calendars to enhance monitoring, and many other difficulties that are to be faced during the first years of the subject's adaptation.

The results of this experience show a positive adoption from students' side, although the subject's increased motivation and final knowledge cannot be expressed by empirical data. Nevertheless, the path chosen to use these methodologies and educational tools is not easy, nor is the adoption of the new EHEA concepts in general. Because of this, the main aspects presented as challenges in the mentioned adaptation process have been described. Those aspects are not only teacher-related, but the students also find before them a new teaching methodology not encountered in the past.

This learning experience has meant a significant novelty for the subject's teachers, who were not trained in this kind of techniques and had to improvise in many occasions. Despite this, the experience can be considered enormously positive; possibly, the students have learned less content related to master class' organization, but it is obvious that they have learned more about other skills, such as group work, search for information, use of collaborative tools, time management, etc. The key issue is whether the balance reached is enough. It would be interesting to develop a comparative study of students under different types of learning.

\section{Acknowledgements}

The authors would like to thank all people who contributed, both directly and indirectly, to this study. We are grateful to the teachers from Engineering Projects Area, who are behind this initiative. We would also like to thank the University of Vigo for its support, training and means provided to us to carry out this experience, and, above all, we are very grateful to the students that have helped us review and reflect on our teaching role, on teaching strategies, on the function and types of assessment, in short, how to help shape skilled, reflexive and self-critical professionals. Thank you for patiently suffering this adaptation process we are all in. 


\section{References}

Álvarez, J.V. (2003). Uso de estándares e-Learning en espacios educativos. Revista Fuentes, $\mathrm{N}^{\mathrm{o}}$ 5, Facultad de CC de la educación. Universidad de Sevilla, July 2003, pp. (153-172), ISSN 1575-7072

Barrows, H.S. \& Tamblyn, R.M. (1980). Problem-Based Learning: An Approach to Medical Education. Springer P. C., ISBN 978-0826128416, New York

Blank, W.; Harwell, S. (1997). Promising practices for connecting high school to the real world, W.E. Blank \& S. Harwell (Eds.), University of South Florida. (ERIC Document Reproduction Service No. ED407586), Tampa (Florida)

Benito, A. \& Cruz, A. (2005). Nuevas claves para la docencia universitaria, Narcea, ISBN 1501-1 / 144 pp., Madrid

Buzón, O. (2005). La incorporación de plataformas virtuales a la enseñanza: una experiencia de formación on-line basada en competencias. RELATEC: Revista Latinoamericana de Tecnología Educativa, Vol. 4, №. 1, 2005, March 2005, pp. (77-100), ISSN 1695-288X

Bruner, J. (1990). Acts of meaning. Harvard University Press, ISBN 0-674-00360-8, Cambridge

Casar, A. (2006). Claroline at the University of Vigo in Spain, adaptations and use. Annual conference of Claroline Users (ACCU), Louvain-la-Neuve (Bélgica), May 2006, Available from: http://www.claroline.net/accu/accu-2006-3.html, Accesed on: 2010-10-14

De Henao, T. (2007). Claroline: an Outsider's Perspective. Annual conference of Claroline Users (ACCU), Vigo (España), May 2007, Available from: http://www.claroline.net/accu/accu-2007-2.html, Accesed on: 2010-10-14

Dewey, J. (1998). How We Think: A Restatement of the Relation of Reflective Thinking to the Educative Process, Houghton Mifflin, ISBN 978-0395897546

Dickinson, K.P.; Soukamneuth, S.; Yu, H.C.; Kimball, M.; D’Amico, R.; Perry, R., Kingsley, C. \& Curan, S.P. (1998). Providing educational services in the Summer Youth Employment and Training Program. Technical assistance guide, Available from: http://www.eric.ed.gov/PDFS/ED420756.pdf, Accesed on: 2010-10-08

Gallego, M. J. (2003). Intervenciones formativas basadas en www para guiar el inicio de la práctica profesional de los docentes. Revista Iberoamericana de Educación, №33, September-December 2003, pp. (11-131). ISSN 1022-6508

Larsen, L.B., Andersen, S.K., Fink, F. \& Granum, E. (2003). Teaching HCI to Engineering Students Using Problem Based Learning. Interact Workshop of IFIP WG 13.1, Zurich (Swiss), September 2003

López, E. \& López, O. (2002). L 'Aprenentatge virtual com a una nova forma d'ensenyar i d' aprendre a través de les tecnologies de la informació i la comunicació. Temps d'Educació, No 26, pp. (407-416). ISSN 0214-7351

Knight, P.T. (2005). El profesorado de Educación superior. Formación para la excelencia, Narcea, ISBN 1487-8/288 PP., Madrid

Miguel Díaz, M. (Dir) (2006). Metodologías de enseñanza y aprendizaje para el desarrollo de competencias. Orientaciones para el profesorado universitario ante el espacio europeo de educación superior, Alianza, ISBN 9788420648187, Madrid 
Oliver, J. (2003). El futuro de la formación de los profesionales informáticos. IX Jornadas de Enseñanza Universitaria de la Informática, Cadiz.

Piaget, J. (2001). The psychology of intelligence (2nd Ed.), Routledge Publishers, ISBN 978-0415254014, London

Pino, M.R \& Soto, J (2010). Evaluation of ICT-based Educative Innovation in Higher Education. The International Journal of Learning, Vol.17, No.1, pp. (243258), ISSN 1447-9494

Plantak, D.; Kirinic,V. \& Klicek, B. (2010). A Comparison of Usability Evaluation Methods for e-Learning Systems, Chapter 27 in DAAAM International Scientific Book 2010, pp. 271-288, B. Katalinic (Ed.), Published by DAAAM International, ISBN 978-3-901509-74-2, ISSN 1726-9687, Vienna, Austria: 1447

Schneckenberg, D. (2004). El e-learning transforma la educación superior. Educar: revista del Depart. de Pedagogia Aplicada, No.33, pp. (147-156), ISSN 0211$819 \mathrm{X}$

Striege, A. \& Rover, D.T. (2002). Problem-Based Learning in an Introductory Computer Enineering Course, 32nd ASEE/IEEE Frontiers in Education Conference, November 2002, Boston (USA)

Tascón, C. (2004). Los mapas conceptuales como instrumento cognitivo para la potenciación de aprendizajes en un entorno e-learning. Anuario de filosofía, psicología y sociología, No. 7, pp. (107-116), ISSN 1139-8132

Thomas, J.W. (2000). A Review of Project Based Learning. Available from: http://www.bie.org/research/study/review_of_project_based_learning_2000, Accesed on: 2010-10-08

Uden, L. \& Dix, A. (2004). Life long learning for software engineers, International Journal of Continuing Engineering Education and Life-Long Learning (IJCEELL), Vol. 14, No. 1-2, pp. (101-110), ISSN 1560-4624

Vygotsky, L. S. (1978). Mind in society: The development of higher psychological processes, Cambridge, MA: Harvard University Press, ISBN: 0-674-57629-2, USA

Woods, D.R., R.M. Felder, A. Rugarcia \& J.E. Stice (2000). The Future of Engineering Education: Part 3. Developing Critical Skills, Chemical Engineering Education, Vol. 34, No. 2, pp. (108-117), ISSN 0009-2479

*** (2010) http://www.ehea.info/ - The European Higher Education Area (2010), Accesed on: 2010-11-16

*** (2011) http://ond.vlaanderen.be/hogeronderwijs/bologna/documents/MDC/ BOLOGNA_DECLARATION1.pdf - Bologna Declaration (1999), Accesed on: 2010-11-16 